\title{
Host Range of Cuscuta gronovii in Raigad and Thane Districts in Konkan Region of Maharashtra, India
}

\author{
V.R. Bangar ${ }^{1 *}$, P. G. Borkar ${ }^{1}$ and S.B. Sable ${ }^{2}$ \\ ${ }^{1}$ Department of Plant Pathology, College of Agriculture, Dapoli, Dr. Balasaheb Sawant \\ Konkan Krishi Vidyapeeth, Dapoli, Dist. Ratnagiri- 415 712(M.S.), India \\ ${ }^{2}$ Department of Plant Pathology and Agricultural Microbiology, Post Graduate Institute, \\ MPKV, Rahuri, India \\ *Corresponding author
}

\section{A B S T R A C T}

\begin{tabular}{|c|c|}
\hline $\begin{array}{l}\text { Cuscuta gronovii, } \\
\text { Pulses, Haustorial } \\
\text { development, } \\
\text { Cuscutaceae, } \\
\text { Convolvulaceae, } \\
\text { Fabaceae, } \\
\text { Asteraceae, } \\
\text { Amaranthaceae, } \\
\text { Eriocaulaceae and } \\
\text { Verbenaceae }\end{array}$ & $\begin{array}{l}\text { Present survey was conducted on dodder (Cuscuta gronovii) which are occupies in } \\
\text { different locations of Raigad and Thane districts of Konkan region of Maharashtra. Dodder } \\
\text { (Cuscuta gronovii) is complete stem parasite. Pulses are cultivated in Konkan region } \\
\text { during Rabi season after harvest of Kharif rice. Cuscuta causes a serious problem in } \\
\text { pulses. The surveys were conducted for host range of Cuscuta gronovii in different } \\
\text { locations of Raigad and Thane districts of Konkan region during 2015-2016. It was } \\
\text { observed that } 37 \text { angiospermic host plants belonging to } 14 \text { families were parasitized by } \text {. } \\
\text { gronovii and grouped into weed hosts ( } 30 \text { spp.), cultivated pulses ( } 4 \text { spp.), other plants ( } 2 \\
\text { spp.) and ornamental plant ( } 1 \mathrm{spp} \text {.). The infection of } \text { C. gronovii was mostly on weed host } \\
\text { and some cultivated pulses. C. gronovii was mostly parasitizing different families like } \\
\text { Fabaceae, Asteraceae, Amaranthaceae and Verbenaceae. In present investigation this was a }\end{array}$ \\
\hline Article Info & \\
\hline $\begin{array}{l}\text { Accepted: } \\
10 \text { March } 2019 \\
\text { Available Online: } \\
10 \text { April } 2019\end{array}$ & $\begin{array}{l}\text { present study also revealed that the shape and mode of development of haustoria was } \\
\text { variable. Haustoria structure of pulses host was highly developed rod or tube like, dome } \\
\text { shaped structure and well established within the host tissue by penetrating epidermis and } \\
\text { cortical tissue towards the vascular bundle of pulse host. }\end{array}$ \\
\hline
\end{tabular}

\section{Introduction}

Cuscuta spp. are parasitic plants of Mediterranean origin. They are worldwide in distribution. In marathi, Cuscuta spp. are also known as Akashwel or Amarwel, is a parasitic angiosperm belonging to the family Convolvulaceae in older references and Cuscutaceae in the more recent publications.
Weber (1986) divided the family Cuscutaceae into two genera i.e. Cuscuta and Grammica, based on the shape of the stigma. The genus Cuscuta is comprised of about 175 species worldwide. The wide geographical distribution of dodder species, their wide host range and the difficulties associated with their control, place them among the most damaging parasites worldwide (Dawson et al., 1994 and 
Holm et al., 1997). Cuscuta are broadly nonspecific, attacks a wide range of plant species including many cultivated plants and dicotyledonous weeds, but rarely the monocotyledonous plants (Wright et al., 2011 and Dawson et al., 1994). Pulses are cultivated in Konkan region during Rabi season after harvest of Kharif rice. There are many reasons for low production of pulses. Out of them phanerogamic plant parasite i.e. Cuscuta infection is major problem.

Cuscuta gronovii infesting cranberry fields in Wisconsin reduced the yield by at least $50 \%$ (Bewick et al., 1988). Out of these 12 species are reported from India (Gaur, 1999) of which C. campestris and $C$. reflexa are most common. In some Indian literature, $C$. chinensis and $C$. trifolii were also reported. Some Cuscuta spp. have important medicinal, pharmacological, industrial and edible values, while others are a threat to the natural ecosystems and agricultural crops (Jayasinghe et al., 2004 and Pandey et al., 2013).

In India, Cuscuta spp. causes a serious problem in oilseeds like niger (Guizotia abyssinica L.), linseed (Linum usitatissimum L.) and pulses like black gram (Vigna mungo L.), green gram (Vigna radiata L.), lentil (Lens culinaris L.), chickpea (Cicer arietinum L.), especially in rice-fallows and fodder crops like lucerne (Medicago sativa L.), berseem (Trifolium spp.) in the states of Andhra Pradesh, Chhattisgarh, Gujarat, Orissa, West Bengal and parts of Madhya Pradesh under rainfed as well as irrigated conditions. It reproduces mainly by seeds. The yield reductions due to Cuscuta are reported to the tune of 60 to 87 per cent in different crops.

In Konkan region of Maharashtra, the Cuscuta gronovii was found to be parasitic on crops of Rabi season. In Raigad and Thane districts, it is serious problem on pulses like beans, green gram, kidney bean, cow pea etc (especially in rice-fallows) in Rabi season. It is also parasitic on the other dicotyledonous crops and weeds. Its parasitic effects reduce the plant vigour and yield. In severe infestation the infested plants may die. (Dalvi et al., 2014) Considering importance of the host plants and parasite, present study on Cuscuta gronovii parasitic on pulses was conducted to know the host range of Cuscuta in Konkan region and its survival.

\section{Materials and Methods}

\section{Survey for host Range of Cuscuta gronovii in Raigad and Thane districts of Konkan region}

For recording the host range of dodder $(C$. gronovii) in Konkan region, in general and around the pulse fields, particularly in rice fallows, along the roadsides and railway track sides etc. dodder spp. were critically observed by undertaking the roving survey. The survey was conducted in the month of SeptemberOctober, 2015 (Kharif) and in the month of January, 2016 (Rabi) in different locations viz., Alibag, Karjat, Khalapur, Mahad, Mangaon, Mhasla, Pen, Poladpur, Roha, Tala Tahsils of Raigad district and Badalpur, Murbad, Shahapur, Ulhasnagar Tahsils of Thane district of Konkan region of Maharashtra. The survey was completed in two rounds by visiting the above places.

The survey was done by just observing the infestation of $C$. gronovii, if any, on all types of cultivated pulse crop fields, weeds, wild plants and shrubs. The plants parasitized by Cuscuta were visually observed for the attachment of vegetative parts of Cuscuta to the host plant. Cultivated pulse host plants were identified basis of haustorial structure and establishment within a host. Samples of cultivated pulse plants parasitized by $C$. gronovii were collected in paper bags during 
survey and brought to the laboratory. It was carried out by made a very thin transverse or cross sections of host parasite attachment zone. This section was placed on glass slide and observed under compound microscope at $10 \mathrm{X}$.

\section{Results and Discussion}

\section{Survey for host range of $C$. gronovii}

Surveys for the host range of $C$. gronovii were conducted during the year 2015-16 in different locations of Raigad and Thane Districts of Konkan region of Maharashtra. The data presented in Table 1 revealed the 37 angiospermic host plants belonging to 14 families were parasitized by $\mathrm{C}$. gronovii and grouped into weed hosts (30 spp.), cultivated pulses (4 spp.), other plants (2 spp.) and ornamental plant (1 spp.). (PLATE I).

Results of survey revealed that parasitism of C. gronovii was mostly on weed hosts, some cultivated pulses and other plants. These results indicate the predominance of $C$. gronovii mostly on dicotyledonous annual as well as perennial host plants and rarely parasitized monocotyledonous plant. $C$. gronovii was predominantly parasitizing on the families viz., Asteraceae and Fabaceae each containing 9 species followed by Amaranthaceae (4 spp.), Verbenaceae (3 spp.), Convolvulaceae and Malvaceae (2 spp.) each.

Remaining 8 families viz., Asclepiadaceae, Boraginaceae, Cyperaceae, Eriocaulaceae, Moraceae, Onagraceae, Poaceae and Rhamnaceae had 1 species each parasitized by $C$. gronovii.

Haustoria structure of pulse host plants was observed. Haustoria was highly developed such as rod or tube like, dome shaped structure and well established within the host tissue by penetrating epidermis and cortical tissue towards the vascular bundle of pulse host (PLATE II).

Present survey also indicated that $C$. gronovii prefers dicotyledonous plants than the monocotyledonous plants. Few monocotyledonous plants viz., Eriocaulon sieboldianum, Paspalum disticum and Cyperus difformis were parasitized by $C$. gronovii.

Distribution of $C$. gronovii was mainly found near the abandoned areas, besides the railway lines (Konkan railway), road side vegetation, herbaceous plants near shallow ditches, in rice fallows lands and in pulses fields as well as around the pulses fields i.e. on weeds and trees on bunds (Plate III). Results of present study are in the conformity with earlier findings of Dawson et al., (1994) and Holm et al., (1997).

The above findings are in closed conformity with the results of Dalvi et al., (2014) who carried out the survey for host range of dodder (C. gronovii) during the year 2012-13 in different localities of Raigad district of Konkan region of Maharashtra and reported that cultivated pulses such as green gram (Vigna radiata L.), black gram (Vigna mungo L.) and chickpea (Cicer arietinum L.) were parasitized by $C$. gronovii in Rabi season.

They also observed that some of the dicotyledonous perennial plants and weeds were parasitized by Cuscuta. Vyas and joshi, 1975 reported that a new record of parasitic dodder on chickpea (Cicer arietinum L.).

Kumar and Kondap, (1992) also reported that the cultivars of green gram and black gram parasitized by Cuscuta spp. Moorthy, et al., (2003) reported that some field crops infested by parasitic Cuscuta spp. Mishra, (2009) also found that pulses plants infested by Cuscuta sp. 
Table.1 Host range of $C$. gronovii from Raigad and Thane districts of Konkan region in Maharashtra

\begin{tabular}{|c|c|c|}
\hline $\begin{array}{l}\text { Sr. } \\
\text { No. }\end{array}$ & Botanical name of host plants & Family \\
\hline \multicolumn{3}{|c|}{ A. Weeds: } \\
\hline 1 & Abelmoschus moschatus Medik. & Malvaceae \\
\hline 2 & Abutilon indicum (L.) Sweet. & Malvaceae \\
\hline 3 & Achyranthus aspera L. & Amaranthaceae \\
\hline 4 & Aeschynomene indica $\mathrm{L}$. & Fabaceae \\
\hline 5 & Ageratum conyzoides $\mathrm{L}$. & Asteraceae \\
\hline 6 & Alternanthera philoxeroides (Mart.) Griceb. & Amaranthaceae \\
\hline 7 & Alternanthera sessilis (L.) DC. & Amaranthaceae \\
\hline 8 & Alysicarpus rugosus (Willd.) & Fabaceae \\
\hline 9 & Amaranthus spinosus L. & Amaranthaceae \\
\hline 10 & Atylosia scarabaeoides L. & Fabaceae \\
\hline 11 & Caesulia axillaris Roxb. & Asteraceae \\
\hline 12 & Calotropis gigantea L. & Asclepiadaceae \\
\hline 13 & Cassia tora $\mathrm{L}$. & Fabaceae \\
\hline 14 & Celosia argentia $\mathrm{L}$. & Amaranthaceae \\
\hline 15 & Chromolaena odorata $\mathrm{L}$. & Asteraceae \\
\hline 16 & Cyperus difformis $\mathrm{L}$. & Cyperaceae \\
\hline 17 & Cythocline purpurea $\mathrm{L}$. & Asteraceae \\
\hline 18 & Eclipta alba $\mathrm{L}$ & Asteraceae \\
\hline 19 & Eriocaulon sieboldianum L. & Eriocaulaceae \\
\hline 20 & Heliotropium indicum L. & Boraginaceae \\
\hline 21 & Ipomea aquatica Forssk. & Convolvulaceae \\
\hline 22 & Ipomea pes-trigridis $\mathrm{L}$. & Convolvulaceae \\
\hline 23 & Lactuca spp. & Asteraceae \\
\hline 24 & Lantana camara $\mathrm{L}$. & Verbenaceae \\
\hline 25 & Ludwigia octovalvis (Jacq.) Raven. & Onagraceae \\
\hline 26 & Paspalum disticum $\mathrm{L}$. & Poaceae \\
\hline 27 & Sphaeranthus indicus L. & Asteraceae \\
\hline 28 & Vicoa indica $\mathrm{L}$. & Asteraceae \\
\hline 29 & Vigna sublobata L. & Fabaceae \\
\hline 30 & Vitex nigundo L. & Verbenaceae \\
\hline \multicolumn{3}{|c|}{ B. Cultivated pulses: } \\
\hline 1 & Cicer arietinum $\mathrm{L}$. & Fabaceae \\
\hline 2 & Lablab purpureus L. & Fabaceae \\
\hline 3 & Vigna mungo L. & Fabaceae \\
\hline 4 & Vigna radiata $\mathrm{L}$. & Fabaceae \\
\hline \multicolumn{3}{|c|}{ C. Other plants (Trees): } \\
\hline 1 & Ficus glomerata Roxb. & Moraceae \\
\hline 2 & Zizyphus jujuba Lam. & Rhamnaceae \\
\hline \multicolumn{3}{|c|}{ D. Ornamental plant: } \\
\hline 1 & Duranta repens L. & Verbenaceae \\
\hline
\end{tabular}


Plate.1 Host plants parasitized by $C$. gronovii recorded during survey

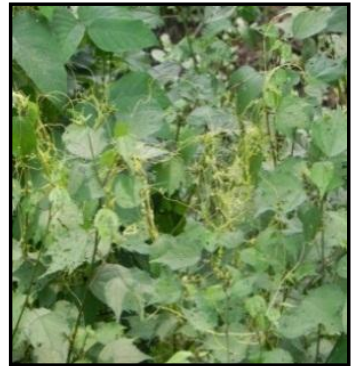

Abelmoschus

moschatus Medik

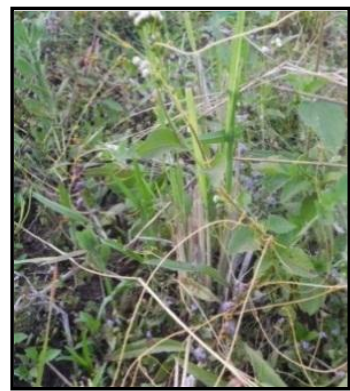

Ageratum

conyzoides L.

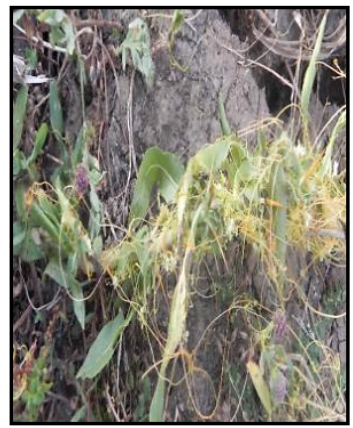

Amaranthus

spinosus L.

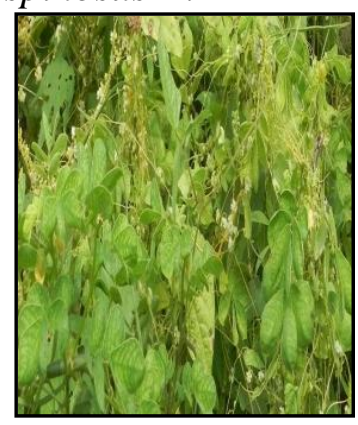

Cassia tora $\mathrm{L}$

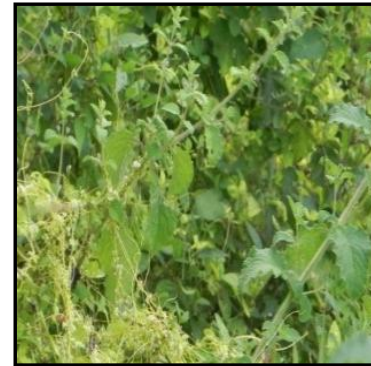

Abutilon indicum

(L.) Sweet.

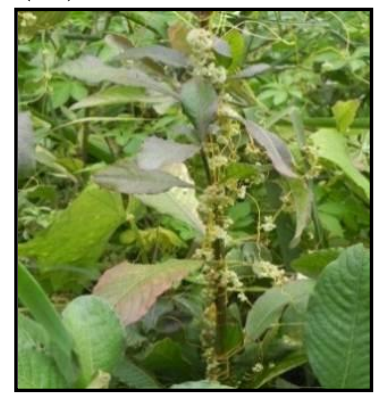

Alternanthera

philoxeroides

(Mart.) Griceb.

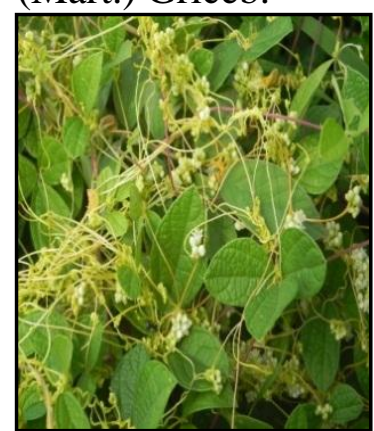

Atylosia

scarabaeoides L.

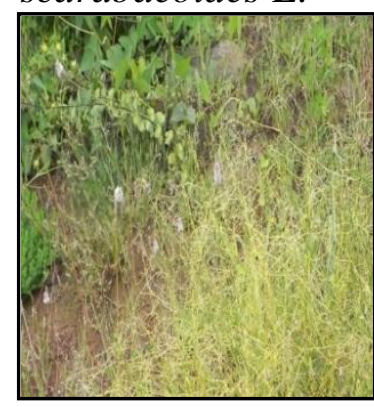

Celosia argentia $\mathrm{L}$.

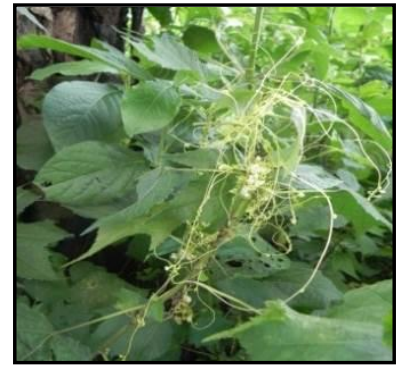

Achyranthus aspera

$\mathrm{L}$.

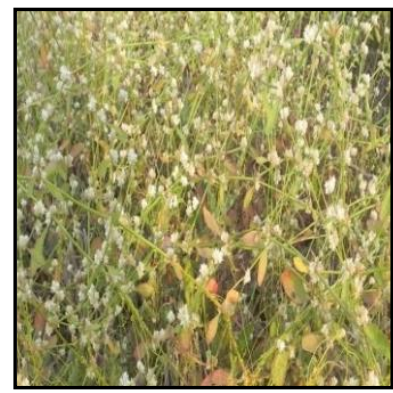

Alternanthera sessilis

(L.) DC.

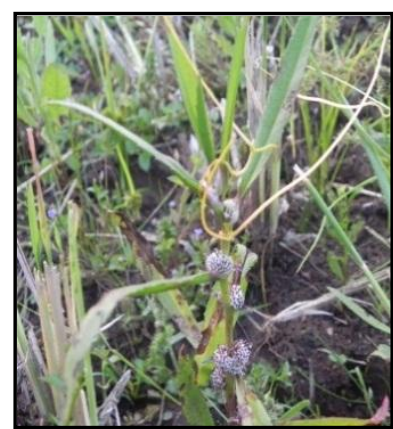

Caesulia axillaris

Roxb.

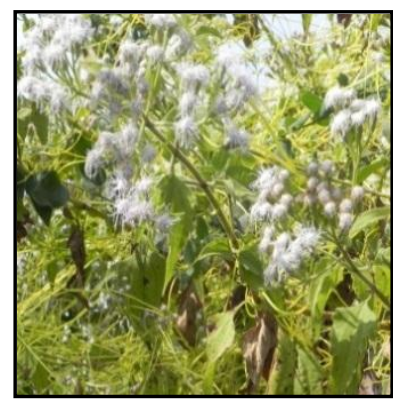

Chromolaena odorata L.

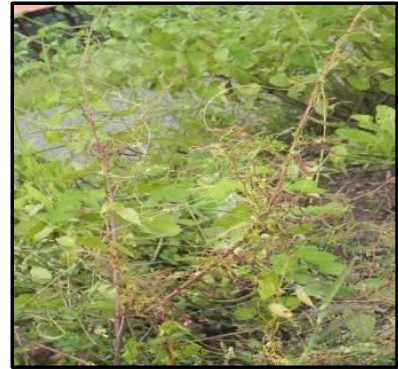

Aeschynomene indica L.

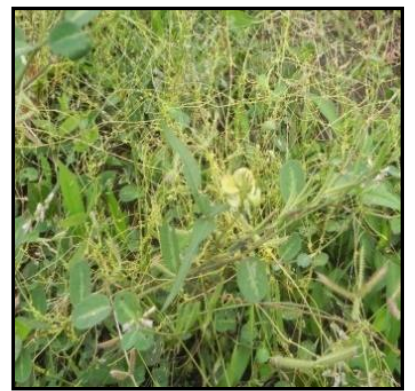

Alysicarpus rugosus (Willd.)

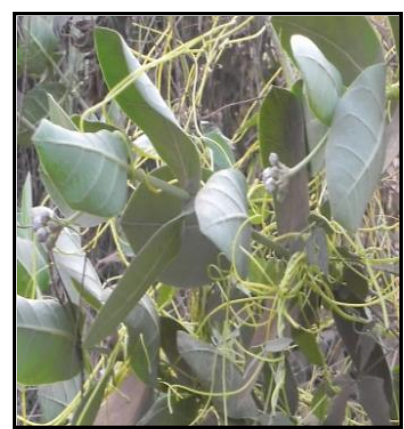

Calotropis gigantea

L.

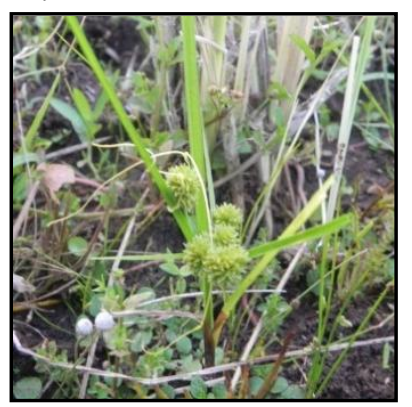

Cyperus difformis L. 


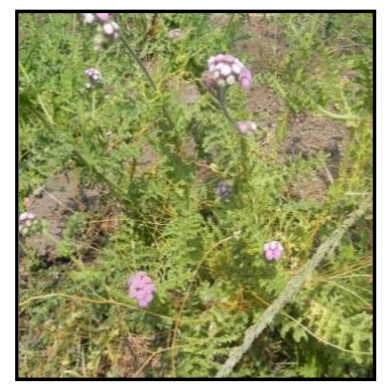

Cythocline

purpurea L.

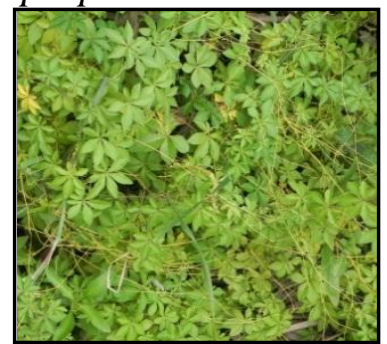

Ipomea pes-trigridis

L.

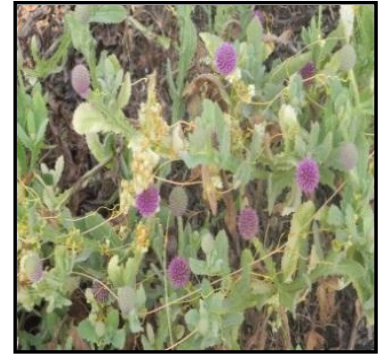

Sphaeranthus

indicus L.

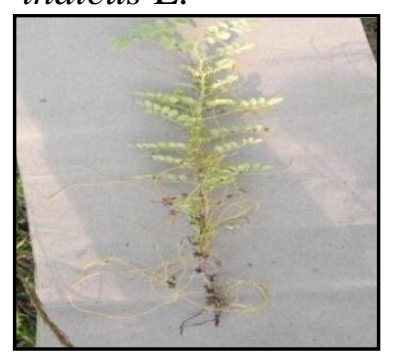

Cicer arietinum $\mathrm{L}$.

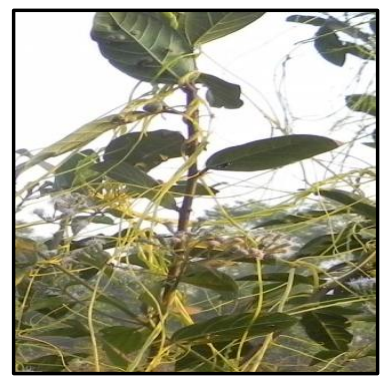

Ficus glomerata

Roxb.

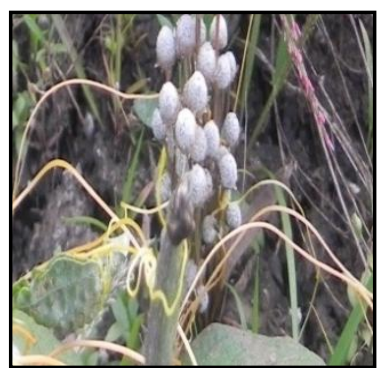

Eclipta alba $\mathrm{L}$.

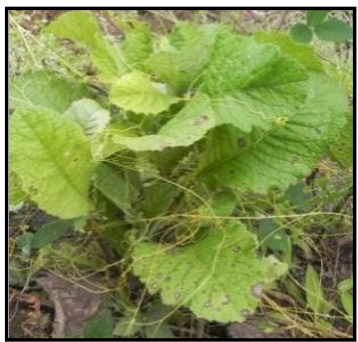

Lactuca spp.

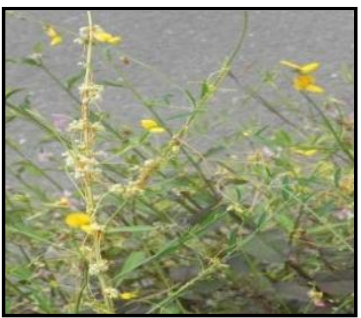

Vicoa indica $\mathrm{L}$.

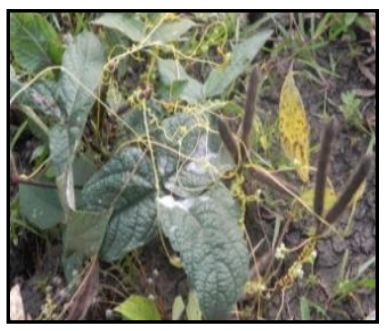

Vigna mungo L.

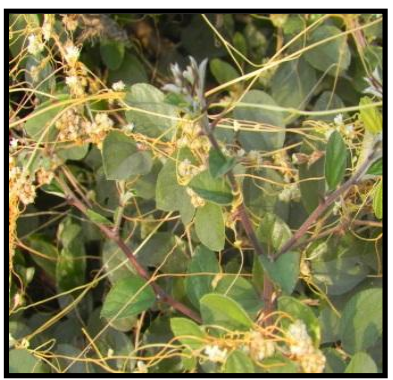

Zizyphus jujuba

Lam.

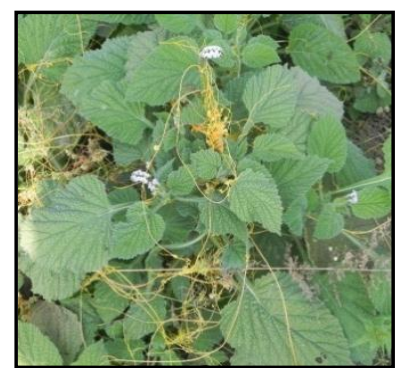

Heliotropium indicum $\mathrm{L}$.

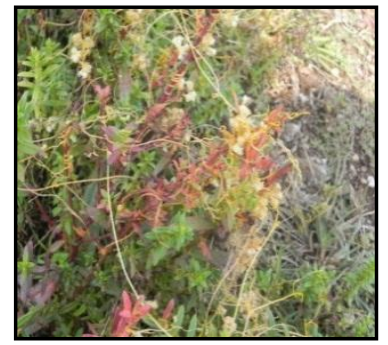

Ludwigia octovalvis (Jacq.) Raven.

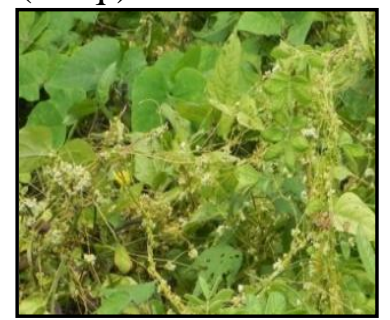

Vigna sublobata L.

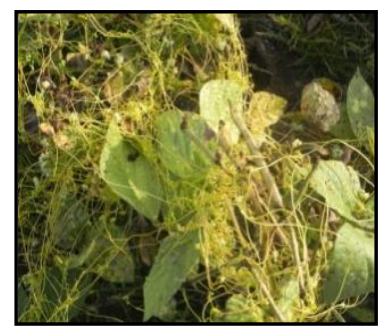

Vigna radiata $\mathrm{L}$.

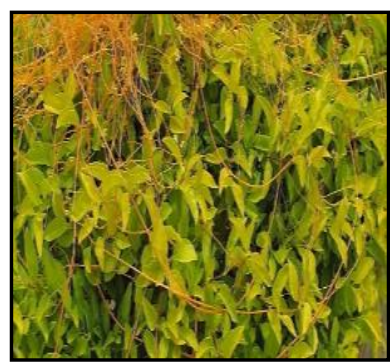

Duranta repens L.

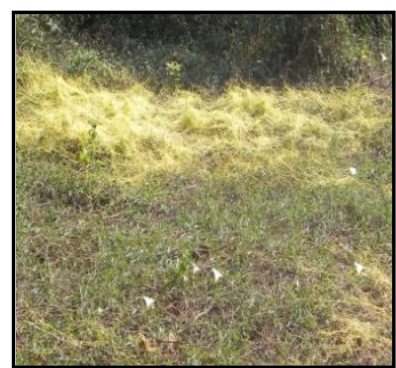

Ipomea aquatica

Forssk.

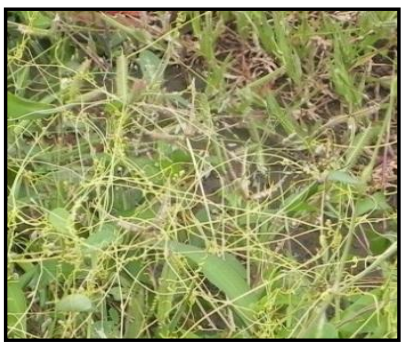

Paspalum disticum L.

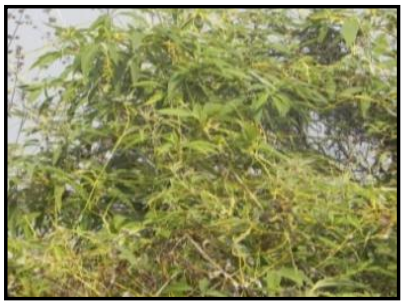

Vitex nigundo L.

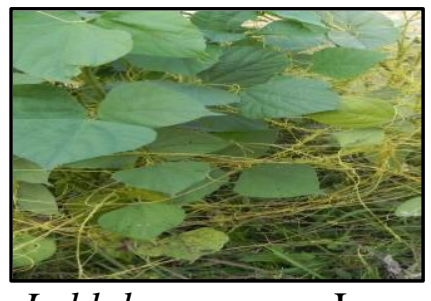

Lablab purpureus L. 


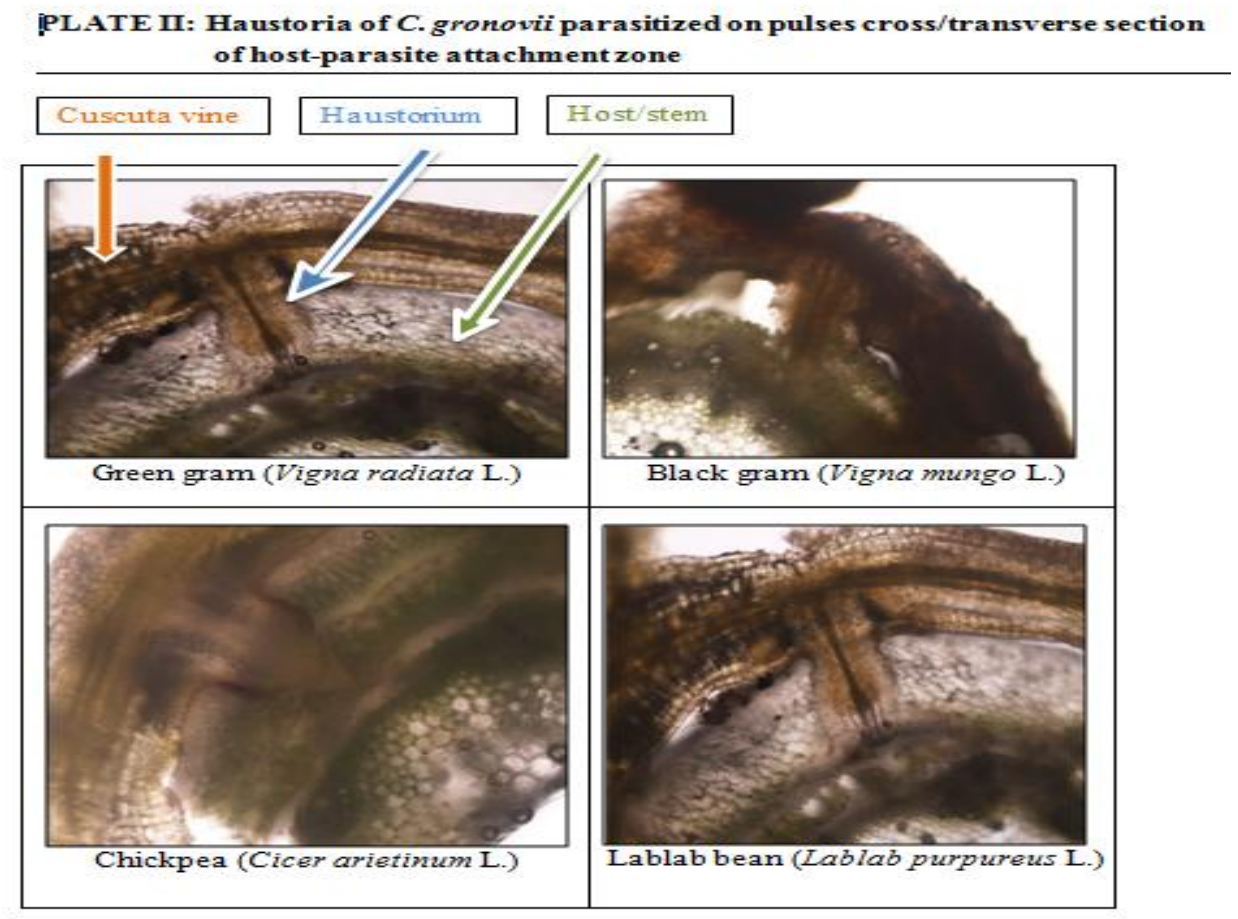

PLATE III: Areas/fields severely parasitized by $C$. gronovii:

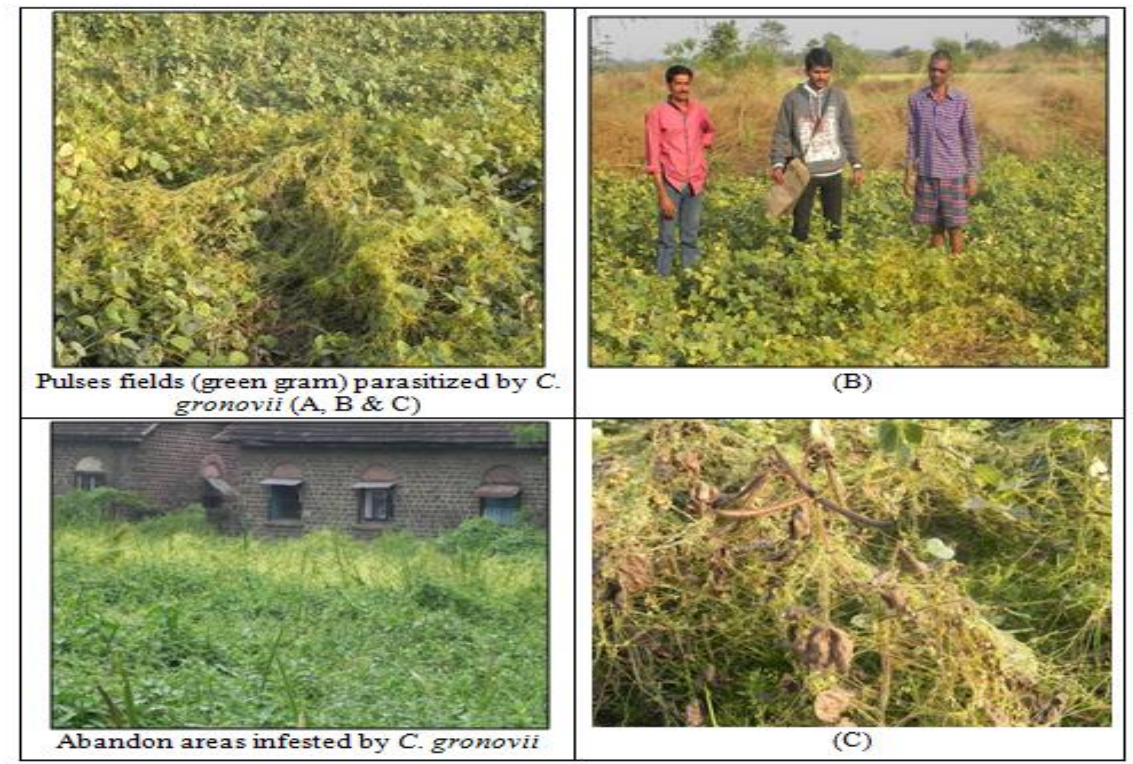

In earlier studies it has already indicated the host parasite relationship of Cuscuta. Bhattarai et al., (1989) carried out survey of C. reflexa and found that 39 plant species, representing 28 families, were reported as being either primary (13 species) or secondary hosts (26 species). Duranta repens was found the most susceptible host plant of C. reflexa. Kapoor and Sharma (2007) found that prevalence of $C$. campestris was observed mostly on wild hosts and only a few cultivated ornamental plant like Duranta 
repens belongs to family Verbenaceae. Also grass i.e. monocotyledonous plant (unidentified) infested by $C$. campestris belongs to families Asteraceae and Poaceae, respectively.

The findings of present investigation are also in accordance with Sarma et al., (2008) who found that attack of $C$. reflexa Roxb was more on Verbenaceae family and reported that infestation of $C$. reflexa Roxb on both Lantana camara L. and Vitex negundo L. and Ziziphus mauritiana Lamk belonging to families like Verbenaceae and Rhamnaceae, respectively. Kanade et al., (2009) who observed the host plants such as Alternanthera triandra and Amranthus viridis belongs to Amaranthaceae family, Lantana camara (Verbenaceae), Ipomea sp. (Convolvulaceae), Calotropis gigantea L. (Asclepiadaceae), Cassia sp. (Fabaceae), Ficus glomerata Roxb. (Moraceae), Vitex negundo Linn. (Verbenaceae) and Zizyphus jujube. There was new report of family Eriocaulaceae plant infected by $C$. gronovii.

In conclusion, prevalence of $C$. gronovii mostly on weed host, some cultivated pulses, dicotyledonous annual as well as perennial host plants and rarely on monocotyledonous plants. C. gronovii was mostly parasitizing different families like Fabaceae, Asteraceae, Amaranthaceae and Verbenaceae. In present investigation this was a new and first report of Cuscuta gronovii parasitizing to weed host of family Eriocaulaceae and also first report of all weed hosts parasitized by $C$. gronovii in Konkan region.

\section{References}

Bewick, T. A., Binning, L. K. and Dana, M. N., 1988. Post attachment control of swamp dodder (Cuscuta gronovii) in cranberry (Vaccinium macrocarpon) and carrot (Daucus carota). Weed
Technology., 2: 166-169.

Bhattarai, T., Bhandary, H. and Shrestha, P., 1989. Host range of Cuscuta reflexa Roxb. in the Kathmandu Valley, Nepal. Plant Protection Quarterly., 4 (2): $78-80$.

Dalvi, M. B., Joshi, M. S. and Chavan, L. S., 2014. Control of Dodder Parsitic on Pulses. Associate Director of Research, Regional Agril. Research Centre, Karjat, Dist. Raigad. Project Report Submitted to Project Director, ATMA, Alibag, Raigad.

Dawson, J. H., Musselman, L. J., Wolswinkel, P. and Dorr, I., 1994. Biology and control of Cuscuta. Rev. Weed Sci. 6: 265-317.

Holm, L., Doll, J., Holm, E., Pancho, J. and Harbinger, J., 1997. World Weeds: Natural Histories and Distribution. John Wiley \& Sons, NY, USA.

Jayasinghe, C., Wijesundara, D. S. A., Tennekoon, K. U. and Marambe, B., 2004. Cuscuta species in the lowlands of Sri Lanka, their host range and host-parasite association. Trop. Agric. Res., 16: 223-241.

Kanade, M. B., Gham S. K. and Patil N. A., 2009. Host Range of Genus Cuscuta in Solapur District of Maharashtra. Bioinfolet., 6 (2): 146-148.

Kapoor, V. and Sharma Y. P., 2007. Host Range, Severity and Intensity of Cuscuta campestris Yuncker Infestations in Jammu Province of Jammu and Kashmir. Indian J. Weed Sci., 39 (1 \& 2): 146-148.

Kumar, R. M. and Kondap, S. M., 1992. Response of greengram and blackgram cultivars to Cuscuta infestation. Ind. J. Plant Protec., 21: 167-171.

Mishra, J. S., 2009. Biology and Management of Cuscuta spp. Indian J. Weed Sci., 41 ( $1 \& 2): 1-11$

Moorthy, B. T. S., Mishra, J. S. and Dubey, 
R. P., 2003. Certain investigations on the parasitic weed Cuscuta in field crops. Ind. J. Weed Sci., 35: 214-216.

Pandey, P. K., Singh, A. K., Singh, S., Pandey, V. and Singh, M. C., 2013. Cuscuta: A Freeloading Weed, their Dilemma and Property. International Journal of Agriculture, Environment \& Biotechnology. 6 (3): 479-486.

Sarma, H., Sarma, C. M. and Bhattacharjya, D. K., 2008. Host Specificity of Cuscuta reflexa Roxb. in the Manas Biosphere Reserve, Indo-Burma Hotspot. International Journal of Plant Production., 2 (2): 175-180.
Vyas, S. C. and Joshi, L. K., 1975. A new record of parasitic dodder on chickpea (Cicer arietinum L.). Current Science., 44: 701-702.

Weber, W. A., 1986. Colorado Flora: Western Slope. Colorado Associated University Press, Boulder.

Wright, M. A. R., Welsh, M. and Costea, M., 2011. Diversity and evolution of the gynoecium in Cuscuta (Convolvulaceae) in relation to their reproductive biology: two styles are better than one. Plant System and Environment., 296: 51-76.

\section{How to cite this article:}

Bangar, V.R., P. G. Borkar and Sable, S.B. 2019. Host Range of Cuscuta gronovii in Raigad and Thane Districts in Konkan Region of Maharashtra, India. Int.J.Curr.Microbiol.App.Sci. 8(04): 1293-1301. doi: https://doi.org/10.20546/ijcmas.2019.804.149 